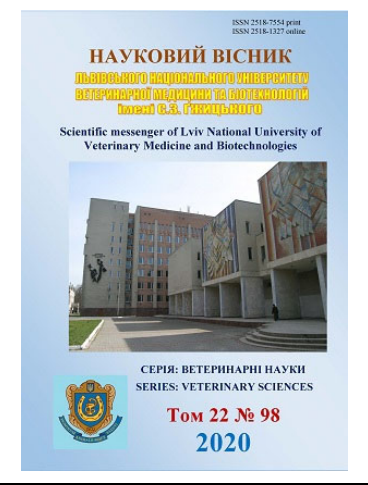

\author{
Науковий вісник Дьвівського національного університету \\ ветеринарної медицини та біотехнологій імені С.3. Гжицького. \\ Серія: Ветеринарні науки \\ Scientific Messenger of Lviv National University \\ of Veterinary Medicine and Biotechnologies. \\ Series: Veterinary sciences
}

UDC 619.616.34:636.8

\title{
Comprehensive treatment of dogs with chronic generalized periodontitis in remission
}

\author{
N. M. Khomyn ${ }^{1}$, A. R. Mysak ${ }^{1}$, S. V. Tsisinska ${ }^{1}$, V. V. Pritsak ${ }^{1}$, N. V. Nazaruk ${ }^{1}$, M. M. Khomyn ${ }^{2}$ \\ ${ }^{1}$ Stepan Gzhytskyi National University of Veterinary Medicine and Biotechnologies Lviv, Ukraine \\ ${ }^{2}$ Institute of Animal Biology NAAS, Lviv, Ukraine
}

Article info

Received 18.03.2020

Received in revised form 24.04.2020

Accepted 25.04.2020

Stepan Gzhytskyi National University of Veterinary Medicine and Biotechnologies Lviv, Pekarska Str., 50, Lviv, 79010, Ukraine.

Tel.: +38-067-894-17-12

E-mail:nadiakhomyn@ukr.net

Institute of Animal Biology of NAAS, Stusa Str., 38, Lviv,

79000, Ukraine.
Khomyn, N. M., Mysak, A. R., Tsisinska, S. V., Pritsak, V. V., Nazaruk, N. V., \& Khomyn, M. M. (2020). Comprehensive treatment of dogs with chronic generalized periodontitis in remission. Scientific Messenger of Lviv National University of Veterinary Medicine and Biotechnologies. Series: Veterinary sciences, 22(98), 57-62. doi: 10.32718/nvlvet9810

It is known that periodontal diseases are a significant part of dental diseases in dogs. Chronic generalized periodontitis deserves the most attention. The disease develops slowly, beginning without visible clinical signs, but later, a combination of certain favorable etiological factors can lead to the loss of the animal's teeth, indigestion, metabolism with serious consequences for the dog. Therefore, the search of the features of the disease and the development of tactics for effective treatment of periodontally ill animals is relevant for modern veterinary dentistry. The aim of the work was to study the features of the course of chronic generalized periodontitis in remission in dogs and to develop tactics for rational treatment of periodontally ill animals. For the study, two groups of animals with chronic generalized periodontitis were formed in remission with 5 dogs in each (control and experimental), selected on the principle of analogues in terms of age and nature of the pathological process. Searches have shown that in chronic generalized periodontitis in remission in dogs there is an increase in the number of pathogenic microflora in the biotopes of the oral cavity, increasing the activity of acid phosphatase, increasing the protein concentration by reducing the content of lysozyme in the oral fluid. It was found that the dogs of the experimental group, after removal of tartar and rehabilitation of the oral cavity, were treated by using to the gums of ceftriaxone, diluted in $1 \%$ lidocaine hydrochloride solution in combination with $30 \%$ dimexid solution 1 time per day for 7 days, anfluron injecteed intramuscularly at the rate of $1 \mathrm{ml} 1$ time per day for 7 days and caforsen $-0.1 \mathrm{ml} / \mathrm{kg}$ per day for 4 weeks. The treatment contributed to the recovery of dogs for 10 days, which is 8 days faster than in the control group.

Key words: dogs, teeth, chlorhexidine, tartar, microflora, inflammation, remission, periodontitis, dental indices, curettage, periodontal pockets.

\section{Комплексне лікування собак за хронічного генералізованого пародонтиту на стадії ремісії}

\author{
Н. М. Хомин ${ }^{1}$, А. Р. Мисак ${ }^{1}$, С. В. Цісінська ${ }^{1}$, В. В. Прицак ${ }^{1}$, Н. В. Назарук ${ }^{1}$, М. М. Хомин ${ }^{2}$ \\ ${ }^{1}$ Львівський національний університет ветеринарної медицини та біотехнологій імені С. 3. Гжицького, \\ м. Львів, Україна \\ ${ }^{2}$ Інститут біології тварин НААН, м. Львів, Україна
}

Відомо, щзо пародонтопатії складають значну частину стоматологічних захворювань у собак. Найбільшої уваги заслуговує хронічний генералізований пародонтит. Захворювання розвивається повільно, спочатку без видимих клінічних ознак, але згодом за поєднання певних сприятливих етіологічних факторів може призвести до втрати твариною зубів, порушення травлення, обміну речовин з достатньо серйозними наслідками для собаки. Тому вивчення особливостей перебігу хвороби та розроблення тактики 
ефективного лікування пародонтологічно хворих тварин є актуальним для сучасної ветеринарної стоматології. Метою роботи було вивчення особливостей перебігу хронічного генералізованого пародонтиту на стадії ремісї̈ у собак та розробити тактику рачіонального лікування пародонтологічно хворих тварин. Для проведення досліджень було сформовано дві групи тварин з хронічним генералізованим пародонтитом на стадї ремісї по 5 собак у кожній (контрольна і дослідна), підібраних за принципом аналогів щодо віку та характеру патологічного процесу. Як показали дослідження, за хронічного генералізованого пародонтиту на стадї ремісї у собак спостерігається збільшення кількості патогенної мікрофлори у біотопах ротової порожнини, підвищення активності кислої фосфатази, збільшення концентрація білка за зниження вмісту лізочиму в ротовій рідині. Встановлено, шчо собак дослідної групи, після зняття зубного каменя та санації ротової порожнини, лікували шляхом аплікації на ясна иефтриаксону, розведеного на 1 \% розчині лідокаїну гідрохлориду в поєднанні з 30 \% розчином димексиду 1 раз на добу протягом 7 діб, анфлурону, введеного внутрішньом'язового з розрахунку 1 мл 1 раз на добу протягом 7 діб та кафорсену - 0,1 мл/кг на добу протягом 4 тижнів. Проведене лікування сприяло одужанню собак протягом 10 діб, що на 8 діб швидще, ніж у контрольній групі.

Ключові слова: собаки, зуби, хлоргексидин, зубний камінь, мікрофлора, запалення, ремісія, пародонтит, стоматологічні індекси, кюретаж, пародонтальні кишені.

\section{Вступ}

Відомо, що масове розповсюдження хвороб пародонта, великий відсоток хворих на пародонтопатії тварин, попередня втрата ними зубів, часті рецидиви свідчать про те, що лікування парондологічно хворих собак є досить актуальним у сучасній ветеринарній стоматологіï (Frolov, 2002; Logan et al., 2002; Southerden \& Gorrel, 2007; Frolov, 2009).

Серед численних причин, що викликають запальний процес у тканинах пародонта, одне 3 головних місць займає зубний наліт, до складу якого входять бактерії, компоненти слини, часточки епітелія ротової порожнини. 3 часом зубний наліт розповсюджується вздовж лінії ясен, а бактерії, що містяться у ньому, секретують токсини і продукти обміну речовин, які викликають запалення тканин пародонта. Воно може призвести до рецесії ясен за оголення коренів або за поширення запального процесу вглиб під ясна $з$ утворенням пародонтальних кишень. При мінералізації зубного нальота утворюється зубний камінь - над'ясенний i під'ясенний. Запалення при цьому переходить на кісткову структуру, і кістка 3 часом резорбується; при цьому зуби стають рухливими i випадають (Vasileva, 2006; Kyrychko \& Zvenihorodska, 2013; Spirina, 2016; Khomyn et al., 2017; 2018).

Тому питання розробки нових ефективних методів і засобів санації ротової порожнини тварин та лікування собак за пародонтопатій, зокрема хронічного генералізованого пародонтиту (ХГП), на стадії ремісії залишається актуальним.

Мета роботи - вивчити особливості перебігу хронічного генералізованого пародонтиту на стадії реміciї у собак та розробити тактику раціонального лікування пародонтологічно хворих тварин.

\section{Матеріал і методи досліджень}

Для проведення досліджень було сформовано дві групи тварин з хронічним генералізованим пародонтитом на стадії ремісії по 5 собак у кожній (контрольна і дослідна), підібраних за принципом аналогів щодо віку та характеру патологічного процесу. Маніпуляції з тваринами проводили під загальною анестезією. Ротову порожнину зрошували $0,12 \%$ розчином хлоргексидину глюконату, проводили видалення над'ясенного і під'ясенного каменя (навколокоренева чистка і вискоблювання під'ясенної ділянки) з подальшим поліруванням поверхні з метою зачистки шорсткостей, що утворюються на поверхні емалі під час проведення процедури зняття каменя та кюретаж пародонтальних кишень. Собак дослідної групи лікували шляхом аплікації на ясна цефтриаксону, розведеного на $1 \%$ розчині лідокаїну гідрохлориду в поєднанні з 30\% розчином димексиду 1 раз на добу протягом 7 діб, анфлурону, введеного внутрішньом'язового 3 розрахунку 1 мл 1 раз на добу протягом 7 діб та кафорсену - 0,1мл/кг на добу протягом 4 тижнів, тимчасом як тварин контрольної групи лікували шляхом внутрішньом'язового введення цефуроксиму, розведеного у воді для ін'яєкцій та per os імунобактерину D iз розрахунку 1 г/гол на добу з питною водою протягом 7 діб.

Клінічні дослідження (галітоз, кровоточивість, болючість, гіперемія, припухлість, стан зубоясневої борозни, зубоясневого прикріплення, рухливість зубів, наявність пародонтальних кишень) проводили шляхом огляду, пальпації та спеціального інструментарію.

Ефективність лікування визначали за станом гігієни ротової порожнини та місцевого імунітету. Для об'єктивного визначення інтенсивності запального процесу в тканинах пародонта були встановлені стоматологічні індекси і проби.

Дослідження біотопів ротової порожнини, а також визначення вмісту кислої фосфатази, білка та лізоциму проводили згідно із загальноприйнятими методиками. Клінічні, стоматологічні, бактеріологічні дослідження проводили до та на 3, 7, 10 добу лікування, біохімічні та імунологічні - до і на 3 та 7 добу.

Отримані числові дані обробляли за допомогою стандартного пакета статистичних програм Microsoft EXCEL.

\section{Результати та їх обговорення}

Встановлено, що серед стоматологічних захворювань у собак близько 80 \% складають хвороби пародонта різного ступеня перебігу, за прогресування яких можливе ураження кісткової тканини, що оточує i підтримує зуби. Здебільшого мова йде про пародонтит, запалення якого охоплює ясна, альвеолярну кістку, цемент зуба і пародонтальну зв'язку, яка $є$ ключовим об'єктом ураження, що визначає рухливість зубів і больові вудчуття (Frolov, 2003; Samojlenko, 2003). 
Відомо також, що основну роль в патогенезі, зокрема пародонтиту, належить бактерійному фактору. У процесі розвитку хвороби число первинно колонізуючих бактерій (грампозитивних аеробних коків) знижується, натомість переважають грамнегативні анаероби і спірохети (Samojlenko, 2003; Frolov, 2008). Загалом роль патогенної мікрофлори у розвитку і перебігу хвороб пародонта достатньо значуща. 3 огляду на це було проведене дослідження щодо кількості МАФАнМ у біотопах ротової порожнини собак за хронічного генералізованого пародонтиту у стадії ремісії (табл. 1).

Встановлено, що в ротовій рідині, яка є зв'язковою ланкою між біотопами ротової порожнини, кількість мікроорганізмів збільшилась у 2,53 разу. В зубних відкладеннях кількість мікроорганізмів збільшилась у 3,31 разу, в зубоясневій борозні - у 1,87 разу, на слизовій оболонці язика - в 1,59 разу, на слизовій оболонці ясен - у 2,10 разу. Найменше зросла кількість мікроорганізмів за хронічного генералізованого пародонтиту на слизовій оболонці піднебіння. Отже, хронічний генералізований пародонтит на стадії ремісії у собак характеризується збільшенням кількості мікроорганізмів в основних біотопах ротової порожнини.

Дослідженнями встановлено, що до початку лікування загальний стан тварин обох груп був пригнічений. Собаки мали середню або нижче середньої вгодованість, що свідчить про недостатнє споживання корму внаслідок порушення акту його прийому. Собаки приймали корм дуже обережно, повільно, часто погано пережовуючи. При цьому інколи скиглили. Має місце галітоз. Оглядом і пальпацією виявлено припухлість ясен, їхню кровоточивість, значне почервоніння, підвищення місцевої температури та болючість. Ясневий край потовщений і має вигляд валика 3 вираженим ціанозом. У тварин спостерігається відкладання над- і під'ясневого каменю, рухливість зубів I ступеня. Наявні пародонтальні кишені глибиною до 5 мм (рис. 1).

\section{Таблиця 1}

Кількість МАФАнМ у біотопах ротової порожнини собак за ХГП на стадії ремісії $(\mathrm{M} \pm \mathrm{m}, \mathrm{n}=5)$

\begin{tabular}{|c|c|c|}
\hline \multirow[b]{2}{*}{ Досліджуваний біотоп } & \multicolumn{2}{|c|}{ Групи } \\
\hline & $\begin{array}{c}\text { контрольна } \\
\text { (клінічно } \\
\text { здорові) }\end{array}$ & $\begin{array}{c}\text { дослідна } \\
\text { (хворі на ХГП) }\end{array}$ \\
\hline $\begin{array}{l}\text { ротова рідина, } \\
\times 10^{7} \mathrm{KУО} / \mathrm{cm}^{3}\end{array}$ & $1,28 \pm 0,10$ & $3,24 \pm 0,36^{* * *}$ \\
\hline 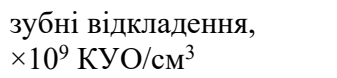 & $1,17 \pm 0,12$ & $3,88 \pm 0,25^{* * *}$ \\
\hline $\begin{array}{l}\text { зубояснева борозна, } \\
\times 10^{4} \mathrm{KУO} / \mathrm{cm}^{3}\end{array}$ & $2,40 \pm 0,17$ & $4,49 \pm 0,37^{* * *}$ \\
\hline $\begin{array}{l}\text { слизова оболонка язика, } \\
\times 10^{5} \mathrm{KУO} / \mathrm{cm}^{3}\end{array}$ & $3,94 \pm 0,35$ & $6,27 \pm 0,45^{* *}$ \\
\hline $\begin{array}{l}\text { слизова оболонка ясен, } \\
\times 10^{3} \text { КУО/см }{ }^{3} \\
\text { слизова оболонка }\end{array}$ & $1,91 \pm 0,14$ & $3,97 \pm 0,59 * * *$ \\
\hline $\begin{array}{l}\text { піднебіння, } \\
\times 10^{2} \mathrm{KУO} / \mathrm{cm}^{3}\end{array}$ & $2,30 \pm 0,18$ & $2,89 \pm 0,67$ \\
\hline
\end{tabular}

Примітка: у цій та подальших таблицях $*-\mathrm{P}<0,05$; ** $-\mathrm{P}<0,01 ; * * *-\mathrm{P}<0,001 *$ - вірогідна різниця порівняно 3 показниками контрольної групи
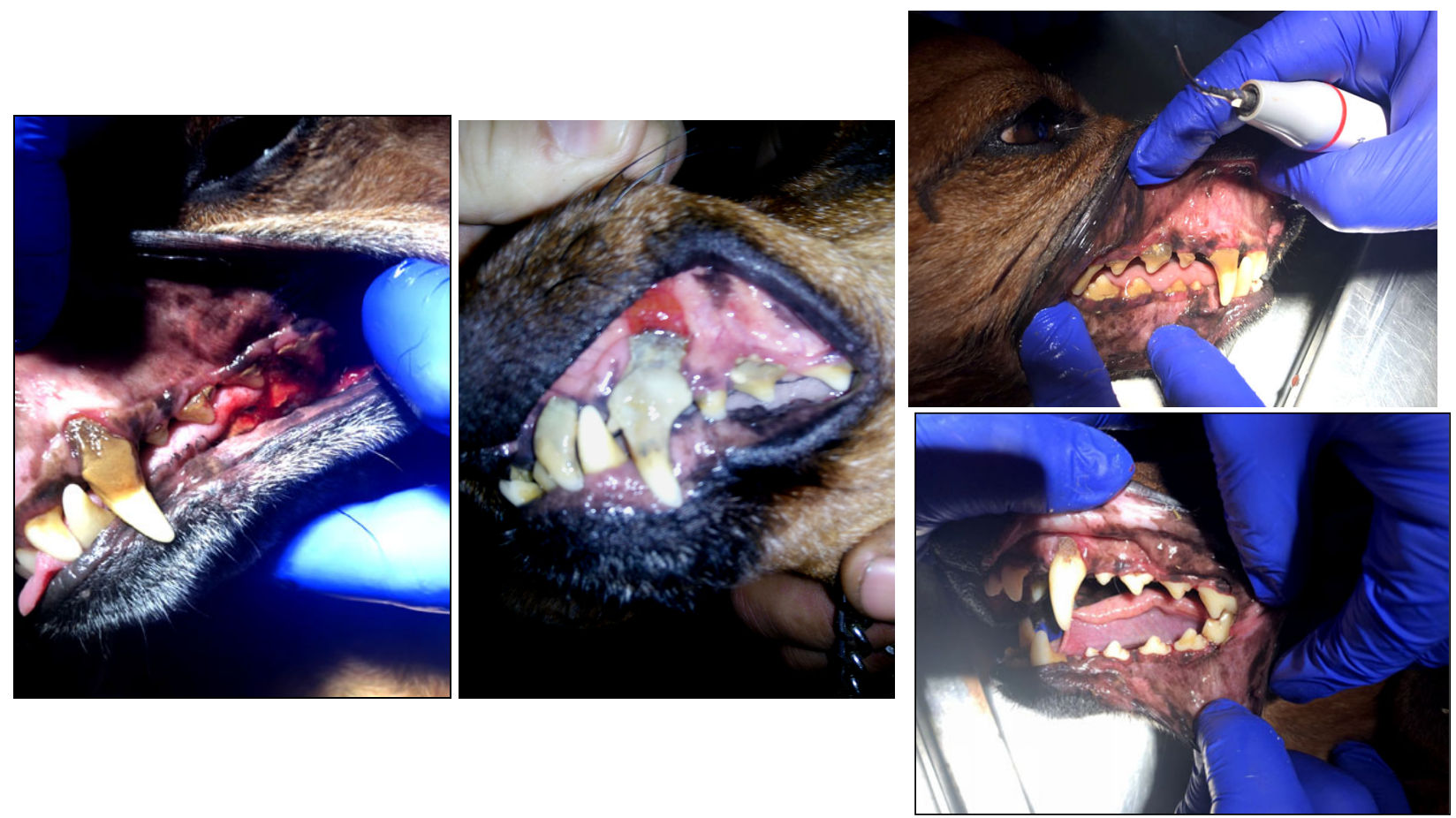

Рис. 1. Хронічний генералізований пародонтит у собак 
У пародонтологічно хворих тварин обох груп кількість МАФАнМ у зубних відкладеннях була великою за високих показників активності кислої фосфатази як маркера стану клітинних мембран, вмісту білка у ротовій рідині - як показника запальних процесів та низької концентрації лізоциму за високих стоматологічних показників (рис. 2-5, табл. 2).

Останні визначали у вигляді пародонтальних індексів для вивчення гігієнічного стану ротової порожнини і поширення патологічного процесу в тканинах пародонта для об'єктивної характеристики клінічних

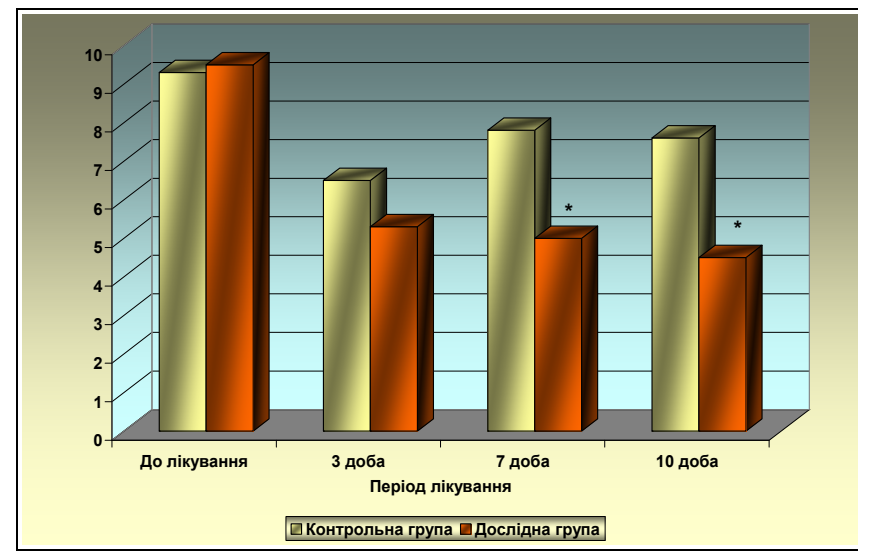

Рис. 2. Кількість МАФАнМ у зубному нальоті собак, хворих на хронічний генералізований пародонтит

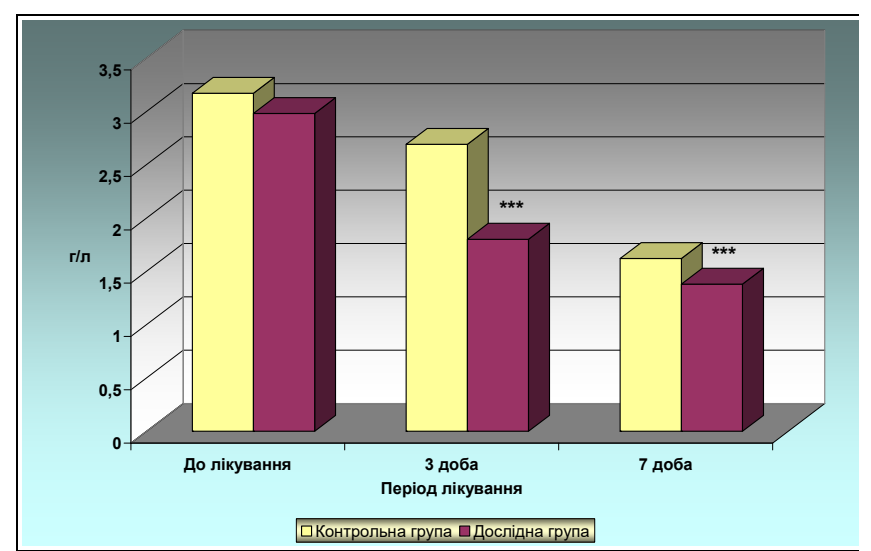

Рис. 4. Вміст білка у ротовій рідині собак із ХГП,

$$
\mathrm{M} \pm \mathrm{m}, \mathrm{n}=5
$$

Підтвердженням цього $є$ зміна величини показників індексів гігієни та клінічного стану пародонта у стоматологічно хворих тварин. Так, на 13,2 \% зменшилась величина папілярно-маргінального індекса за від'ємних показників індекса кровоточивості та індекса гігієни, що свідчить про якісну гігієну ротової порожнини тварин дослідної групи, а зменшення на 8,4 \% йодного число Свракова свідчить про зменшення інтенсивності запального процесу пародонта та $\epsilon$ об’єктивним тестом проведеної протизапальної терапіï.

Крім цього, кількість МАФАнМ у зубному нальоті собак дослідної групи зменшилась у 1,67 разу, активність кислої фосфатази знизилась на 8,6 \% і становить $0,64 \pm 0,010$ мккат/л, вміст білка у ротовій рідині зменшився на $33,1 \%$, що складає $1,80 \pm 0,120$ г/л за збі- проявів захворювання.

Через три доби після застосування розробленого методу лікування загальний стан собак дослідної групи був задовільний, вони краще поїдали корм. Припухлість, болючість, місцева температура були незначні за деякого потовщення ясневого краю, слабо вираженого почервоніння та галітозу, що свідчить про зменшення ознак запалення, тимчасом як у собак контрольної групи ще зберігалися ознаки гострого запального процесу.

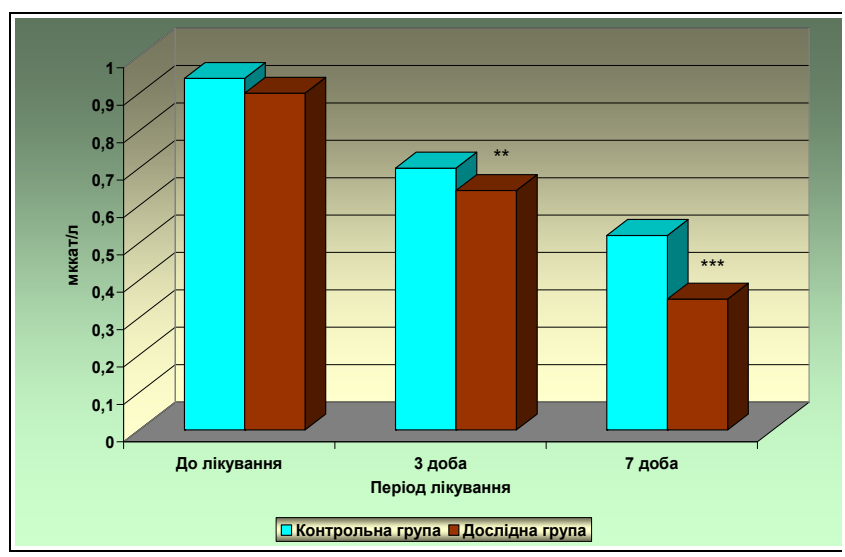

Рис. 3. Активність кислої фосфатази у ротовій рідині собак із ХГП, $\mathrm{M} \pm \mathrm{m}, \mathrm{n}=5$

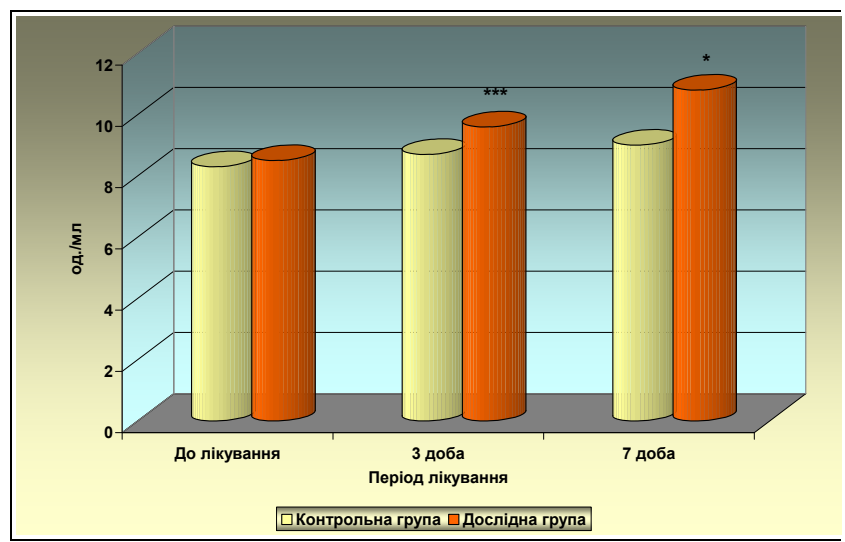

Рис. 5. Вміст лізоциму в ротовій рідині собак із ХГП, $\mathrm{M} \pm \mathrm{m}, \mathrm{n}=5$

льшення концентрації лізоциму на 10,3 \%, яка становить $9,6 \pm 0,04$ од./мл.

На 7-у добу від початку лікування загальний стан собак за хронічного генералізованого пародонтиту був задовільний, апетит збережений, спостерігалися слабо виражені ознаки місцевого запального процесу за відсутності галітозу та зменшення майже вдвічі пародонтальної кишені, яка становить 3 мм. Величина папілярно-маргінального індекса зменшилась на $17,8 \%$ за відсутності інших досліджуваних стоматологічних показників, що свідчить про позитивну динаміку перебігу захворювання, тимчасом як у собак контрольної групи збереглися болючість, припухлість ясен, почервоніння, галітоз, що свідчить про збереження ознак запалення. 
Таблиця 2

Динаміка показників індексів гігієни та клінічного стану пародонта у собак, хворих на хронічний генералізований пародонтит, $\mathrm{M} \pm \mathrm{m}, \mathrm{n}=5$

\begin{tabular}{|c|c|c|c|c|}
\hline \multirow{2}{*}{ Група } & \multirow{2}{*}{ До лікування } & \multicolumn{3}{|c|}{ Доба від початку лікування } \\
\hline & & 3 & 7 & 10 \\
\hline \multicolumn{5}{|c|}{ Проба Шиллера-Писарєва (йодне число Свракова) } \\
\hline контрольна & $2,93 \pm 0,22$ & $1,79 \pm 0,20$ & $1,14 \pm 0,05$ & Негативна \\
\hline дослідна & $2,97 \pm 0,20$ & $1,64 \pm 0,11$ & Негативна & Негативна \\
\hline \multicolumn{5}{|c|}{ Індекс кровоточивості } \\
\hline контрольна & $2,71 \pm 0,06$ & $1,45 \pm 0,01$ & 0 & 0 \\
\hline дослідна & $2,80 \pm 0,04$ & 0 & 0 & 0 \\
\hline \multicolumn{5}{|c|}{ Папілярно-маргінальний індекс } \\
\hline контрольна & $87,4 \pm 2,69$ & $68,7 \pm 2,46$ & $32,0 \pm 1,36$ & $11,0 \pm 089$ \\
\hline дослідна & $85,9 \pm 3,12$ & $59,6 \pm 2,12 *$ & $23,1 \pm 1,24 * *$ & 0 \\
\hline \multicolumn{5}{|c|}{ Індекс гігієни Green-Vermillion } \\
\hline контрольна & $2,43 \pm 0,12$ & $1,12 \pm 0,05$ & 0 & 0 \\
\hline дослідна & $2,43 \pm 0,10$ & 0 & 0 & 0 \\
\hline
\end{tabular}

Кількість мікроорганізмів у зубному нальоті зменшилась в 1,54 разу, активність кислої фосфатази знизилась на $32,7 \%$, вміст білка у ротовій рідині - на $24,8 \%$ за збільшення концентрації лізоциму на 20,0 \%, що становить відповідно 0,35 \pm 0,010 мккат/л, $1,38 \pm 0,020$ г/л та 10,8 $\pm 0,42$ од./мл.

На десяту добу лікування загальний стан собак дослідної групи задовільний, ознаки місцевого запального процесу відсутні, усі досліджувані показники перебували в межах фізіологічної норми, тимчасом як схожі клінічні ознаки у тварин контрольної групи спостерігались лише на 18 добу.

Загалом лікування собак дослідної групи тривало 10 діб, а контрольної - на 8 діб довше і завершилося на 18 добу.

Отже, застосування $з$ лікувальної метою собакам, хворим на хронічний генералізований пародонти, на стадії ремісії цефтриаксону, розведеного лідокаїном, у поєднанні з $30 \%$ розчином димексиду 1 раз на добу протягом 7 діб шляхом аплікації на ясна, анфлурону, введеного внутрішньом'язового по 1 мл 1 раз на добу протягом 7 діб та кафорсену - 0,1мл/кг на добу протягом 4 тижнів сприяє одужанню пародонтологічно хворих тварин за 10 діб, що підтверджується показниками клінічних, стоматологічних, мікробіологічних, біохімічних та імунологічних досліджень.

\section{Висновки}

1. За хронічного генералізованого пародонтиту на стадії ремісії у собак спостерігається збільшена кількість патогенної мікрофлори у біотопах ротової порожнини, підвищена активність кислої фосфатази, збільшена концентрація білка за низького вмісту лізоциму в ротовій рідині.

2. Застосування собакам 3 хронічним генералізованим пародонтитом на стадії ремісії після зняття зубного каменя та санації ротової порожнини цефтриаксону, розведеного на $1 \%$ розчині лідокаїну гідрохлориду в поєднанні з 30 \% розчином димексиду 1 раз на добу протягом 7 діб шляхом аплікації на ясна, анфлурону, введеного внутрішньом'язового по 1 мл 1 раз на добу протягом 7 діб та кафорсену - у кількості
0,1 мл/кг на добу протягом 4 тижнів сприяє одужанню пародонтологічно хворих тварин протягом 10 діб.

Перспективи подальших досліджень. Дослідження будуть спрямовані на розробку нових заходів профілактики хронічного генералізованого пародонтиту в собак.

\section{References}

Frolov, V. V. (2002). Rasprostranenie zabolevanij zubochelyustnoj sistemy u sobak. Veterinariya Povolzhya, 3, 33-34 (in Russian).

Frolov, V. V. (2003). Bolezni zubov i polosti rta u sobak. M.: Akvarium Buk (in Russian).

Frolov, V. V. (2008). Parodontologiya. Osnovnyie problemyi diagnostiki i lecheniya parodonta u sobak. Veterinarnaya klinika, 10(77), 34-35 (in Russian).

Frolov, V. V. (2009). Ostryie i hronicheskie bolezni paradonta u sobak. Trudy VIII Mizhnarodnoyi naukovo-praktichnoyi veterinarnoyi konferentsiyi $\mathrm{Z}$ problem dribnyh tvaryn. Uman, 154-159 (in Russian).

Khomyn, N., Mysak, A., Iglitskej, I., Pritsak, V., \& Semeniyk, N. (2017). Treatment of dogs for periodontal diseases. Scientific Messenger of LNU of Veterinary Medicine and Biotechnologies. Series: Veterinary Sciences, 19(82), 170-174. https://nvlvet.com.ua/index.php/journal/article/view/1 359.

Khomyn, N., Mysak, A., Iglitskej, I., Pritsak, V., Semeniyk, N., \& Nazaruk, N. (2018). Dental diseases in cats. Scientific Messenger of LNU of Veterinary Medicine and Biotechnologies. Series: Veterinary Sciences, 20(83), 282-285. doi: 10.15421/nvlvet8356.

Logan, E., Finney, O., \& Hefferren, J. (2002). Effects of a dental food on plaque accumulation and gingival health in dogs. Journal of Veterinary Dentistry, 19(1), 15-18. doi: 10.1177/089875640201900102.

Kyrychko, B. P., \& Zvenihorodska, T. V. (2013). Osoblyvosti patohenezu ta likuvannia khvorob parodontu $\mathrm{v}$ domashnikh kotiv. Visnyk Poltavskoi derzhavnoi ahrarnoi akademii, 2, 95-97. https:/www.pdaa.edu.ua/sites/default/files/visnyk/201 3/02/95.pdf (in Ukrainian). 
Samojlenko, A. V. (2003). Suchasni aspekty etiologiyi, patogenezu ta likuvannya riznyh klinichnyh variantiv generalizovanogo parodontitu: avtoref. dis. ... doktora med. nauk. 14.01.22 "Stomatologiya". Odesa (in Ukrainian).

Southerden, P., \& Gorrel, C. (2007). Treatment of a case of refractory feline chronic gingivostomatitis with feline recombinant interferon mega. Journal of Small Animal Practice, 48(2), 104-106. doi: 10.1111/j.17485827.2006.00166.x.
Spirina, A. S. (2016). Stomatologicheskie zabolevaniya. Bolezni parodonta u sobak i koshek. Mir veterinarii, 4, 50-54. (in Russian).

Vasileva, M. B. (2006). Vospalitelnyie zabolevaniya parodonta u sobak. Avtoref. dis... na soisk. nauch. stepeni kand. vet. nauk: spets.16.00.05 "Veterinarnaya hirurgiya". Sankt-Peterburg (in Russian). 